\title{
Effect of salt stress on germination and early seedling growth of rice (Oryza sativa L.)
}

\author{
M. A. Hakim ${ }^{1,2 \star}$, A. S. Juraimi ${ }^{3}$, M. Begum ${ }^{1}$, M. M. Hanafi ${ }^{1}$, Mohd R. Ismail ${ }^{3}$ and A. Selamat ${ }^{3}$ \\ ${ }^{1}$ Institute of Tropical Agriculture, University Putra Malaysia 43400 UPM Serdang, Selangor, Malaysia. \\ ${ }^{2}$ Department of Agril. Chemistry, Faculty of Agriculture, HSTU, Dinajpur 5200, Bangladesh. \\ ${ }^{3}$ Department of Crop Science, Faculty of Agriculture, University Putra Malaysia 43400 UPM Serdang, Selangor, \\ Malaysia.
}

Accepted 22 December, 2009

\begin{abstract}
The response of twelve rice varieties against six salinity levels $\left(0,4,8,12,16\right.$ and $\left.20 \mathrm{dS} \mathrm{m}^{-1}\right)$ were studied at germination and early seedling stages. Data were analyzed using SAS and means were separated by LSD for final germination percentage (FGP), speed of germination (SG), germination energy percentage (GE\%), plumule and radical length and plumule and radical dry weight. Based on dry matter yield reduction, rice varieties were classified as tolerant (T), moderately tolerant (MT), moderately susceptible (MS) or susceptible (S). Germination was completely arrested at $20 \mathrm{dS} \mathrm{m}^{-1}$ salt concentration. Salinity decreased FGP, SG, GE \% and led to reduction in shoot and root length and dry weight in all varieties and the magnitude of reduction increased with increasing salinity stress. Rice varieties MR211, IR20, BR40 and MR232 showed greater salt tolerance during germination (germinated at $12 \mathrm{dS} \mathrm{m}^{-1}$ salinity). However, MR211, MR232 and IR20 performed better based on dry matter yield reduction. The result suggested that MR211, MR232 and IR20 might be used for further study of salinity effect on growth processes and physiological consequences at advanced stage of growth, since salt tolerance of a crop at germination and early seedling stage may not correspond to that at advanced stage.
\end{abstract}

Key words: Germination, seedling, rice, salinity stress, $\mathrm{NaCl}$.

\section{INTRODUCTION}

Crops are often exposed to salinity immediately after planting in saline soil or in areas inundated by sea water or irrigated with brackish water. The major inhibitory effect of salinity on plant growth and development has been attributed to osmotic inhibition of water availability as well as the toxic effect of salt ions responsible for salinization. Nutritional imbalance caused by such ions leads to reduction in photosynthetic efficiency and other physiological disorders (Yeo and Flowers, 1983; Yeo et al., 1990). The global extent of primary salt-affected soils is about $955 \mathrm{M}$ ha, while secondary salinization affected some $77 \mathrm{M} \mathrm{ha}$, with $50 \%$ of these in irrigated areas

*Corresponding author. E-mail: ahakim_uni@yahoo.com or ahakimupm@gmail.com. Tel: +6-0149291096
(Metternichi and Zinck, 2003). Salinity is a major problem over a vast area in South and South-East Asia (Massoud, 1974). In India 20.24, Indonesia 13.21, Malaysia 4.58, Bangladesh 2.85 and Thailand 1.46 million ha is affected by salinity (Akbar and Ponnamperuma, 1992). On the other hand, in arid and semi arid regions, limited water and hot dry climates frequently cause salinity problem that limit or prevent crop production. At low concentrations, salt suppresses plant growth and at higher concentration can cause death (Michael et al., 2004). It has also been reported that under saline conditions, germination ability of seeds differ from one crop to another and even a significant variation is observed amongst the different varieties of the same crop (Asana and Kale, 1965, Maas and Hoffman, 1977). Khan et al. (1997) observed that rice varieties showed a great variation in germination due to salinity effect. 
According to the classification of crop tolerance to salinity, the rice crop is within the sensitive division from 0 to $8 \mathrm{dS} \mathrm{m}^{-1}$ (Maas et al., 1986). The susceptibility of rice to salinity stress varies with growth stages. Heenan et al. (1988) and Lutts et al. (1995) reported that rice is extremely sensitive to salinity during germination, young seedling and early developmental stages for most commonly used rice varieties. However, in contrast, Khan et al. (1997) observed that rice is relatively salt tolerant at germination and in some cases is not affected significantly up to 16.3 $\mathrm{dS} \mathrm{m}^{-1}$ of salinity. In general, rice becomes very sensitive at the young seedling stage, which impacts the stand density in salt affected fields (Lutts et al., 1996). It is necessary to identify the sensitivity and tolerance level of a variety at early seedling stages for successful crop production in a saline environment. Therefore, this study was conducted to identify the salt-tolerance rice variety(s) at early seedling establishment and to determine their salt tolerance levels.

\section{MATERIALS AND METHODS}

The experiment was conducted in the laboratory of weed science, University Putra Malaysia during the period of November 2008 to March 2009. Seeds of 12 different rice varieties used in the study were collected from Bangladesh [IR20, BR29, BR40 and Pokkali (a salt tolerant check)] and Malaysia (MR33, MR68, MR84, MR52, MR211, MR219, MR220 and MR232). Healthy, uniform seeds of all varieties were surface sterilized with $1 \%$ mercuric chloride for $5 \mathrm{~min}$ and repeatedly washed with distilled water and surface dried using tissue papers. Twenty seeds for each cultivar in each treatment were allowed to germinate on a filter paper in $9 \mathrm{~cm}$ diameter Petri dishes. Each filter paper were moistened with salt solutions $(\mathrm{NaCl})$ of 0 (distilled water) as a control, $4,8,12,16$ or $20 \mathrm{dS} \mathrm{m}^{-1}$ salt concentrations according to the treatments. Sodium chloride (Batch\# 088K0089, SIGMA-ALORICH Co., USA) was used to prepare the salt solution because it was safe without causing any precipitation of different ions (Aslam et al., 1993). $10 \mathrm{ml}$ of appropriate solution was applied to each Petri dish. The Petri dishes were arranged in completely randomized design (CRD) with four replications for each treatment. Germination room temperature was maintained $25 \pm 1{ }^{\circ} \mathrm{C}$ with $12 \mathrm{~h}$ daylight. The number of seeds that sprouted and germinated was counted daily up to 9 days. Seedling shoot and root length of ten randomly selected seedlings from each replication were measured at the time of harvest ( 9 days after treatment application) with a scale. Shoot dry weight and root dry weight (10 seedlings) were recorded after oven drying at $70^{\circ} \mathrm{C}$ for $72 \mathrm{~h}$. After final count, speed of germination (SG), final germination percent (FGP) and germination energy percentage (GE \%) were calculated by the following formulae (Ellis and Robert, 1981; Ruan et al., 2002).

$\mathrm{SG}=\frac{\text { Number of germinated seeds }}{\text { Days of first count }}+\ldots \ldots \ldots \ldots . .+\frac{\text { Number of germinated seeds }}{\text { Days of final count }}$

GE $(\%)=\frac{\text { Number of germinated seeds at } 4 \text { DAS }}{\text { Total number of seed tested }} \times 100$

FGP $=\frac{\text { Number final germinated seeds }}{\text { Total number of seed tested }} \times 100$

Varieties were classified based as tolerant ( $T=0-20 \%$ reduction), moderately tolerant (MT $=21-41 \%$ reduction), moderately susceptible ( $\mathrm{MS}=41-60 \%$ reduction) and susceptible $(\mathrm{S}=>60 \%$ reduction) on their total dry matter (plumule and radicle) reduction due to different levels of salt impositions (Fageria, 1985).

This experiment was repeated twice to determine the consistency of results of various varieties against different levels of salt concentrations. Data were analyzed using Analysis of Variance method (ANOVA) and means were separated by Least Significant Difference (LSD) using Statistical Analysis System (SAS, version 9.0).

\section{RESULTS AND DISCUSSION}

\section{Final germination percentage (FGP)}

At $20 \mathrm{dS} \mathrm{m}^{-1}$ salinity, germination was completely inhibited for varieties. Germination percentages were inversely related to salt concentration level. The percentage of germination significantly decreased in all varieties due to increasing salinity level (Table 1). At the salinity level of 4 dS $\mathrm{m}^{-1}$, a higher germination percentage of more than $90 \%$ was observed from the varieties MR52 and MR 211, which were statistically similar with four other varieties MR219, MR232, BR40 and salt tolerant check 'Pokkali'. The other four varieties IR20, MR33, MR68 and MR84 were capable of germinating at rates of 80 to $90 \%$. The lowest germination percentage $<70 \%$ was observed for the varieties of MR220 and BR29. Similar trend with decreasing germination percentage was also observed for salinity level at $8 \mathrm{dS} \mathrm{m}^{-1}$ (Table 1). Germination less than $80 \%$ mainly occurred at and above $12 \mathrm{dS} \mathrm{m}^{-1}$ salt concentrations for all rice varieties except MR211. However, variety differences were visible at $16 \mathrm{dS} \mathrm{m}^{-1}$ salinity level. Significantly, highest germination percentage was found in MR232, which was identical to variety MR211. Among the tested varieties, MR52, MR 211, MR 232, BR 40 and IR20 were the superior in germination under saline condition at $12 \mathrm{dS} \mathrm{m}^{-1}$ in comparison to salt tolerant cultivar Pokkali. The variability in salinity tolerance among rice varieties at germination have been reported (Reddy and Vaid, 1983; Mondal et al., 1988). Salinity results in poor stand due to decrease in the rate of seed germination. Presumably, the osmotic effect due to salinity was the main inhibitory factor that reduced germination as indicated by Akbar and Ponnamperuma (1982).

\section{Speed of germination (SG)}

The mean values of SG of the rice varieties at different levels of salinity are presented in Table 2 . The speed of germination was decreased as the salinity levels increased. Irrespective of varieties, the highest mean SG was found at the control and the least was at $16 \mathrm{dS} \mathrm{m}^{-1}$. At lower electrical conductivity (EC) level of $4 \mathrm{dS} \mathrm{m}^{-1}$, the variety Pokkali, MR211, MR219 and BR40 showed better speed of germination (SG) followed by IR20, MR33, MR68, MR84, MR52 and MR232 and the least SG was observed from the rest of the varieties. At $8 \mathrm{dS} \mathrm{m}$, varieties IR20, MR84, MR52, MR211, MR219, MR232 
Table 1. Effect of salinity on final germination percentage of rice varieties.

\begin{tabular}{|c|c|c|c|c|c|}
\hline \multirow{2}{*}{ Variety } & \multicolumn{5}{|c|}{ Salinity levels ${\left.\mathbf{( d S ~} \mathbf{~}^{-1}\right)}^{\mathbf{1}}$} \\
\cline { 2 - 6 } & $\mathbf{0}$ & $\mathbf{4}$ & $\mathbf{8}$ & $\mathbf{1 2}$ & $\mathbf{1 6}$ \\
\hline IR 20 & $96.0 \mathrm{a}$ & $88.75 \mathrm{bc}$ & $77.50 \mathrm{bc}$ & $68.88 \mathrm{~b}$ & $45.0 \mathrm{~b}$ \\
Pokkali & $96.00 \mathrm{a}$ & $90.00 \mathrm{ab}$ & $82.50 \mathrm{abc}$ & $60.50 \mathrm{c}$ & $40.0 \mathrm{c}$ \\
MR 33 & $90.63 \mathrm{~b}$ & $83.13 \mathrm{~d}$ & $76.88 \mathrm{c}$ & $58.75 \mathrm{~cd}$ & $31.88 \mathrm{~cd}$ \\
MR68 & $93.63 \mathrm{ab}$ & $84.38 \mathrm{~cd}$ & $76.88 \mathrm{c}$ & $51.88 \mathrm{~d}$ & $11.25 \mathrm{e}$ \\
MR 84 & $94.63 \mathrm{ab}$ & $85.88 \mathrm{~cd}$ & $78.13 \mathrm{abc}$ & $54.13 \mathrm{~cd}$ & $37.38 \mathrm{c}$ \\
MR 52 & $97.38 \mathrm{a}$ & $95.00 \mathrm{a}$ & $87.00 \mathrm{a}$ & $73.13 \mathrm{~b}$ & $55.38 \mathrm{~b}$ \\
MR 211 & $97.13 \mathrm{a}$ & $95.88 \mathrm{a}$ & $88.38 \mathrm{a}$ & $84.38 \mathrm{a}$ & $61.25 \mathrm{ab}$ \\
MR 219 & $95.63 \mathrm{ab}$ & $91.25 \mathrm{ab}$ & $78.13 \mathrm{bc}$ & $54.38 \mathrm{~cd}$ & $16.25 \mathrm{de}$ \\
MR 220 & $94.13 \mathrm{ab}$ & $65.63 \mathrm{e}$ & $58.75 \mathrm{~d}$ & $40.0 \mathrm{e}$ & $11.0 \mathrm{e}$ \\
MR 232 & $96.00 \mathrm{a}$ & $91.00 \mathrm{ab}$ & $87.38 \mathrm{a}$ & $73.63 \mathrm{~b}$ & $63.25 \mathrm{a}$ \\
BR 29 & $91.88 \mathrm{~b}$ & $66.88 \mathrm{e}$ & $51.38 \mathrm{e}$ & $38.0 \mathrm{e}$ & $19.38 \mathrm{~d}$ \\
BR 40 & $96.00 \mathrm{a}$ & $91.00 \mathrm{ab}$ & $83.38 \mathrm{ab}$ & $75.75 \mathrm{~b}$ & $43.38 \mathrm{c}$ \\
\hline
\end{tabular}

Means with the same letter in the columns do not differ significantly $(P \geq 0.05)$.

Table 2. Effect of salinity on germination speed of rice varieties.

\begin{tabular}{|c|c|c|c|c|c|}
\hline \multirow{2}{*}{ Variety } & \multicolumn{5}{|c|}{ Salinity levels (dS $\mathbf{~ m}^{-1}$ ) } \\
\cline { 2 - 6 } & $\mathbf{0}$ & $\mathbf{4}$ & $\mathbf{8}$ & $\mathbf{1 2}$ & $\mathbf{1 6}$ \\
\hline IR 20 & $19.00 \mathrm{ab}$ & $17.78 \mathrm{bc}$ & $15.68 \mathrm{a}$ & $10.66 \mathrm{a}$ & $5.70 \mathrm{a}$ \\
Pokkali & $20.16 \mathrm{a}$ & $18.20 \mathrm{a}$ & $12.81 \mathrm{e}$ & $7.68 \mathrm{~d}$ & $0.25 \mathrm{e}$ \\
MR 33 & $17.98 \mathrm{~b}$ & $15.84 \mathrm{~d}$ & $9.71 \mathrm{f}$ & $6.48 \mathrm{ef}$ & $2.71 \mathrm{c}$ \\
MR68 & $19.02 \mathrm{ab}$ & $17.00 \mathrm{bc}$ & $9.23 \mathrm{f}$ & $6.10 \mathrm{f}$ & $0.13 \mathrm{e}$ \\
MR 84 & $19.81 \mathrm{a}$ & $17.00 \mathrm{bc}$ & $14.88 \mathrm{ab}$ & $8.33 \mathrm{c}$ & $3.09 \mathrm{bc}$ \\
MR 52 & $19.83 \mathrm{a}$ & $16.39 \mathrm{c}$ & $13.10 \mathrm{~d}$ & $7.47 \mathrm{de}$ & $2.63 \mathrm{c}$ \\
MR 211 & $19.5 \mathrm{ab}$ & $18.51 \mathrm{a}$ & $13.85 \mathrm{c}$ & $10.31 \mathrm{ab}$ & $2.53 \mathrm{c}$ \\
MR 219 & $19.14 \mathrm{ab}$ & $17.59 \mathrm{ab}$ & $14.4 \mathrm{bc}$ & $6.51 \mathrm{ef}$ & $1.34 \mathrm{~cd}$ \\
MR 220 & $14.01 \mathrm{c}$ & $11.35 \mathrm{e}$ & $5.88 \mathrm{~h}$ & $2.14 \mathrm{~g}$ & $0.28 \mathrm{e}$ \\
MR 232 & $19.33 \mathrm{a}$ & $17.33 \mathrm{~b}$ & $13.90 \mathrm{bc}$ & $8.07 \mathrm{~d}$ & $2.92 \mathrm{bc}$ \\
BR 29 & $12.78 \mathrm{~d}$ & $11.00 \mathrm{e}$ & $7.79 \mathrm{~g}$ & $1.58 \mathrm{~g}$ & $0.10 \mathrm{e}$ \\
BR 40 & $20.05 \mathrm{a}$ & $18.34 \mathrm{a}$ & $14.76 \mathrm{ab}$ & $9.45 \mathrm{~b}$ & $2.53 \mathrm{c}$ \\
\hline
\end{tabular}

Means with the same letter in the columns do not differ significantly $(P \geq 0.05)$.

and BR40 had higher SG compared to control. With the increase of salinity to $12 \mathrm{dS} \mathrm{m}^{-1}$, a few number of varieties IR20, MR232, MR211 and BR40 showed higher SG value compared to control. At EC level of $16 \mathrm{dS} \mathrm{m}^{-1}$, although IR20 maintained its higher speed of germination compared to other varieties, it reduced $70 \%$ of SG compared to nonsaline condition (Table 2). The decreasing tendency of $S G$ due to increasing salinity was in the conformity with the reports of others (Mohammed et al., 1989; Khan et al., 1997). The reduction of speed of germination at high salt levels might be mainly due to osmotic stress (Heenan et al., 1988).

\section{Germination energy (GE \%)}

Germination energy was observed at 4th day after soaking of seed and varietal differences were observed in relation to GE\% under saline condition. With the increased in the concentration of $\mathrm{NaCl}$, germination energy was reduced significantly (Table 3). At salinity level of $4 \mathrm{dS} \mathrm{m}$ ${ }^{1}$ varieties BR40, MR232, MR84, MR211, MR219, MR52 and IR20 showed higher or identical GE\% compared to check variety Pokkali. While the salinity level increased upto $12 \mathrm{dS} \mathrm{m}^{-1}$ only four varieties e.g. BR40, MR232, MR211 and IR20 showed better GE\% compared to check 
Table 3. Effect of salinity on germination energy (\%) of rice varieties.

\begin{tabular}{|l|c|c|c|c|c|}
\hline \multirow{2}{*}{ Variety } & \multicolumn{5}{|c|}{ Salinity levels $\mathbf{( d S ~}^{-\mathbf{1}}$ ) } \\
\cline { 2 - 6 } & $\mathbf{0}$ & $\mathbf{4}$ & $\mathbf{8}$ & $\mathbf{1 2}$ & $\mathbf{1 6}$ \\
\hline IR 20 & $65.38 \mathrm{bc}$ & $53.75 \mathrm{c}$ & $43.87 \mathrm{bc}$ & $23.50 \mathrm{~b}$ & 0.0 \\
Pokkali & $68.38 \mathrm{c}$ & $53.75 \mathrm{c}$ & $40.00 \mathrm{~cd}$ & $17.5 \mathrm{c}$ & 0.0 \\
MR 33 & $60.00 \mathrm{~d}$ & $46.63 \mathrm{~d}$ & $26.25 \mathrm{ef}$ & $0.0 \mathrm{f}$ & 0.0 \\
MR68 & $60.0 \mathrm{~cd}$ & $31.88 \mathrm{ef}$ & $19.38 \mathrm{fg}$ & $0.0 \mathrm{f}$ & 0.0 \\
MR 84 & $62.0 \mathrm{~cd}$ & $60.88 \mathrm{~b}$ & $34.0 \mathrm{~d}$ & $11.0 \mathrm{~d}$ & 0.0 \\
MR 52 & $70.63 \mathrm{ab}$ & $57.75 \mathrm{bc}$ & $33.13 \mathrm{de}$ & $13.38 \mathrm{~cd}$ & 0.0 \\
MR 211 & $75.13 \mathrm{a}$ & $60.00 \mathrm{bc}$ & $45.63 \mathrm{ab}$ & $22.5 \mathrm{~b}$ & 0.0 \\
MR 219 & $61.00 \mathrm{~cd}$ & $58.50 \mathrm{bc}$ & $13.75 \mathrm{gh}$ & $5.63 \mathrm{e}$ & 0.0 \\
MR 220 & $44.75 \mathrm{e}$ & $27.5 \mathrm{f}$ & $11.25 \mathrm{~h}$ & $0.0 \mathrm{f}$ & 0.0 \\
MR 232 & $64.38 \mathrm{~cd}$ & $61.63 \mathrm{~b}$ & $49.38 \mathrm{ab}$ & $23.75 \mathrm{~b}$ & 0.0 \\
BR 29 & $48.75 \mathrm{e}$ & $37.50 \mathrm{e}$ & $25.63 \mathrm{ef}$ & $0.0 \mathrm{f}$ & 0.0 \\
BR 40 & $74.75 \mathrm{a}$ & $73.00 \mathrm{a}$ & $52.5 \mathrm{a}$ & $29.38 \mathrm{a}$ & 0.0 \\
\hline
\end{tabular}

Means with the same letter in the columns do not differ significantly $(P \geq 0.05)$.

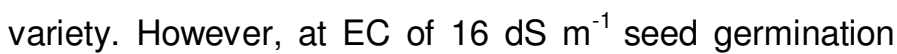
did not occur for all varieties. The result agreed with the work of Karim et al. (1992), Khan et al. (1997) that salinity delays germination processes. Folkard and Wopereis (2001) reported that salinity delayed germination in rice with increasing salt stress. In this study, some of the variety had high FGP but low GE\%, which means that most of the seeds from these varieties might be germinated after 4 days. The varieties with high GE\% value at specific salinity level obviously would be of higher competitive advantages than the varieties having lower GE\% value for capturing environmental and edaphic resources.

\section{Plumule and radicle length}

Plumule length of all the rice varieties declined in all the salt treatments relative to the control and with increase in salinity (Figure 1). However, plumule length reduction was less than $20 \%$ at salt concentration of $4 \mathrm{dS} \mathrm{m}^{-1}$ except for variety BR29 (24\% reduction). At salinity level upto $8 \mathrm{dS} \mathrm{m}^{-1}$, the check variety Pokkali showed better performance followed by MR211 and MR232 and the least performance was observed on MR68 and BR29. At this salt concentration level, plumule length reduction was around $32-40 \%$ for the varieties MR211, MR232, MR33, Pokkali and M52, seven other varieties had $41-49 \%$. With further increase of salinity at $12 \mathrm{dS} \mathrm{m} \mathrm{m}^{-1}$, the reduction percentage was $48-65 \%$. Although varieties MR232 and Pokkali had produced significantly higher plumule length at this salt concentration level compared to others, it was only 52 and $61 \%$ of the control. At 16 dS $\mathrm{m}^{-1}$, the differences of plumule length of varieties were obscure due to serious reduction in height including control variety except IR20, MR211 and MR232. Reduction of seedling height is a common phenomenon of many crop plants grown under saline conditions (Javed and Khan, 1995; Karim et al., 1992; Amin et al., 1996).
Similarly, radical length was also decreased with increased salinity (Figure 2). Radicle length was more suppressed than plumule by salinity at each specific salt concentration level. At all salinity level variety, Pokkali, MR232 and MR 211 produced significantly higher radical length compared to other varieties and BR29 produced lowest radical length. The gradual decrease in root length with the increase in salinity as observed might be due to more inhibitory effect of $\mathrm{NaCl}$ salt to root growth compared to that of shoot growth (Rahman et al., 2001).

\section{Plumule and radicle dry weight}

Plumule dry weight was inversely related to salt concentration (Table 4). It was relatively less sensitive to salt than radical dry weight especially at higher salt concentrations. On the average, over all cultivars at 4, 8, 12 and $16 \mathrm{dS} \mathrm{m}^{-1}$ salinity, plumule dry weight were reduced to about $23,46,64$ and $84 \%$, respectively, of the control, while radical dry weight were more reduced about $31,58,75$ and $88 \%$, respectively, of the control (Tables 4 and 5). Cultivars also differed in the response of plumule dry weight to salt concentration. At the lowest salt concentration $\left(4 \mathrm{dS} \mathrm{m}^{-1}\right)$, the greatest reduction in plumule dry weight was observed in MR 84 (59\%), whilst in all other varieties, reduction range was $13-34 \%$ relative to the control. At $8 \mathrm{dS} \mathrm{m}^{-1}$, variety difference were pronounced; IR20, MR33, MR68, MR52 and MR211 had about $24-40 \%$ reductions, five other varieties had 42 $58 \%$ and only two varieties MR84 and BR29 had 68 $71 \%$. At $12 \mathrm{dS} \mathrm{m}^{-1}$ reduction in plumule dry weight ranged from $46-86 \%$. The smallest reduction was observed in MR33 and MR211 (about 50\%) and the greatest was in BR29 (about 85\%). At $16 \mathrm{dS} \mathrm{m}^{-1}$, reduction was much higher (69-95\%) and all rice varieties were salt susceptible. In this study, at all salinity levels, plumule dry weight of MR211 was significantly less affected and was com- 

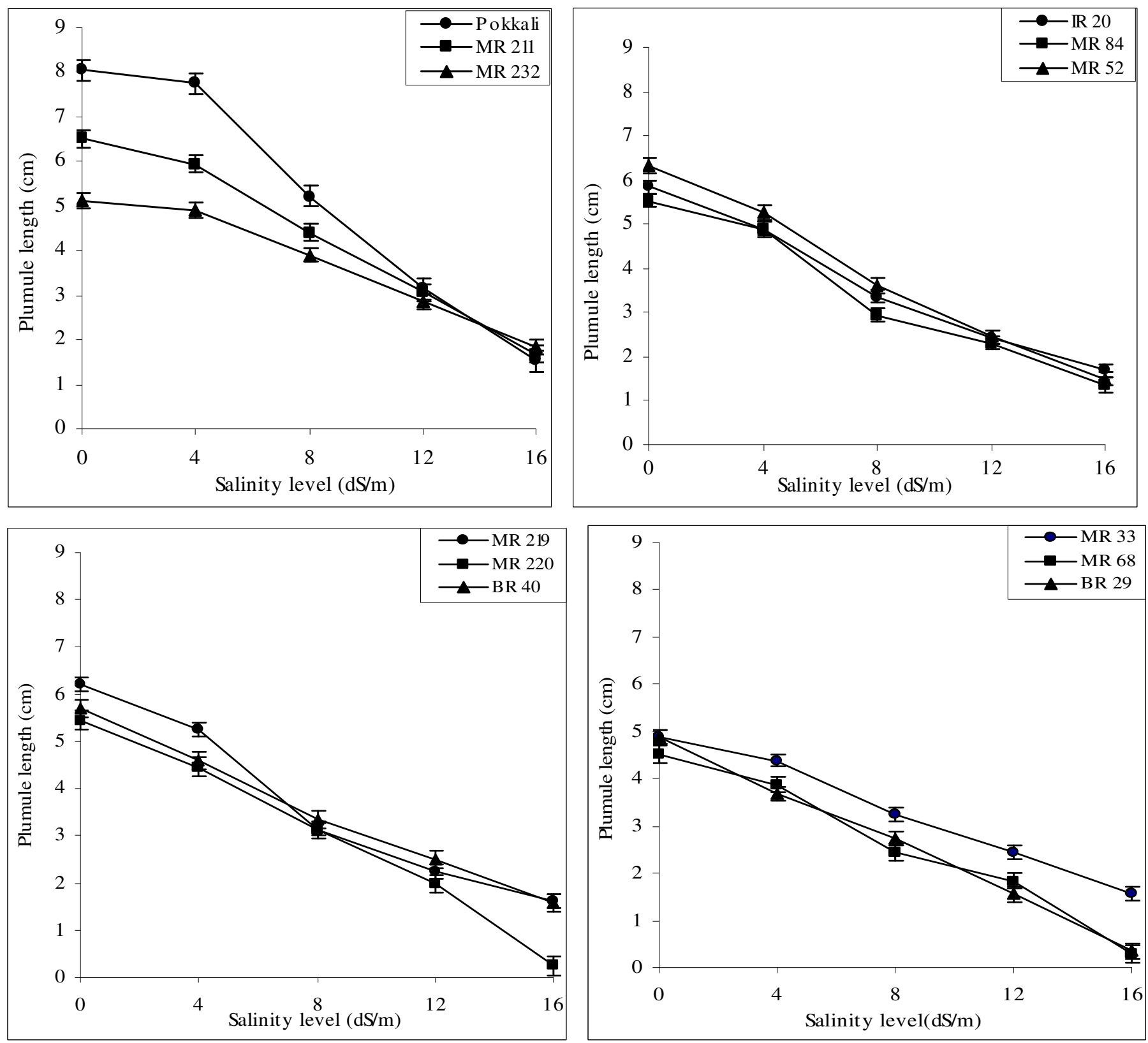

Figure 1. Effect of salinity on plumule length $(\mathrm{cm})$ of different rice varieties.

parable to saline tolerant check variety Pokkali, while variety BR29 showed highest salt sensitivity in all salinity treatments (Table 6).

The radicle dry weight was decreased with increasing salinity levels. Varieties differences were pronounced in this character. At high level of salinity (12 and $16 \mathrm{dS} \mathrm{m}^{-1}$ ), dry matter reduction in all the variety was serious. At the lowest salt concentration $\left(4 \mathrm{dS} \mathrm{m}^{-1}\right)$, radical dry weight of all the varieties were reduced to about $17-36 \%$ of the control, whilst Pokkali and MR220 reduced with tremendous amount of 53 and $63 \%$, respectively. Similar trend was also observed for EC $8 \mathrm{dS} \mathrm{m}^{-1}$. But from statistical point of view, Pokkali showed the highest radical dry weight at $4 \mathrm{dS} \mathrm{m}^{-1}$ as compared to all other varieties. At 8 dS $\mathrm{m}^{-1}$ EC level IR-20 showed highest radical dry weight and lowest was observed by MR68, MR220 and MR29. Varieties MR211, Pokkali, MR52 and MR232 produced second highest radical dry weight at that salinity level. Similarly, Jamil and Rha (2007) observed that shoot length, root lengths and dry weight were decreased with increasing salt stress. Trangenic lines T- 99 and T- 112 had shown greater performance at early seedling growth as compared to two other trangenic lines T- 115 and T121. 

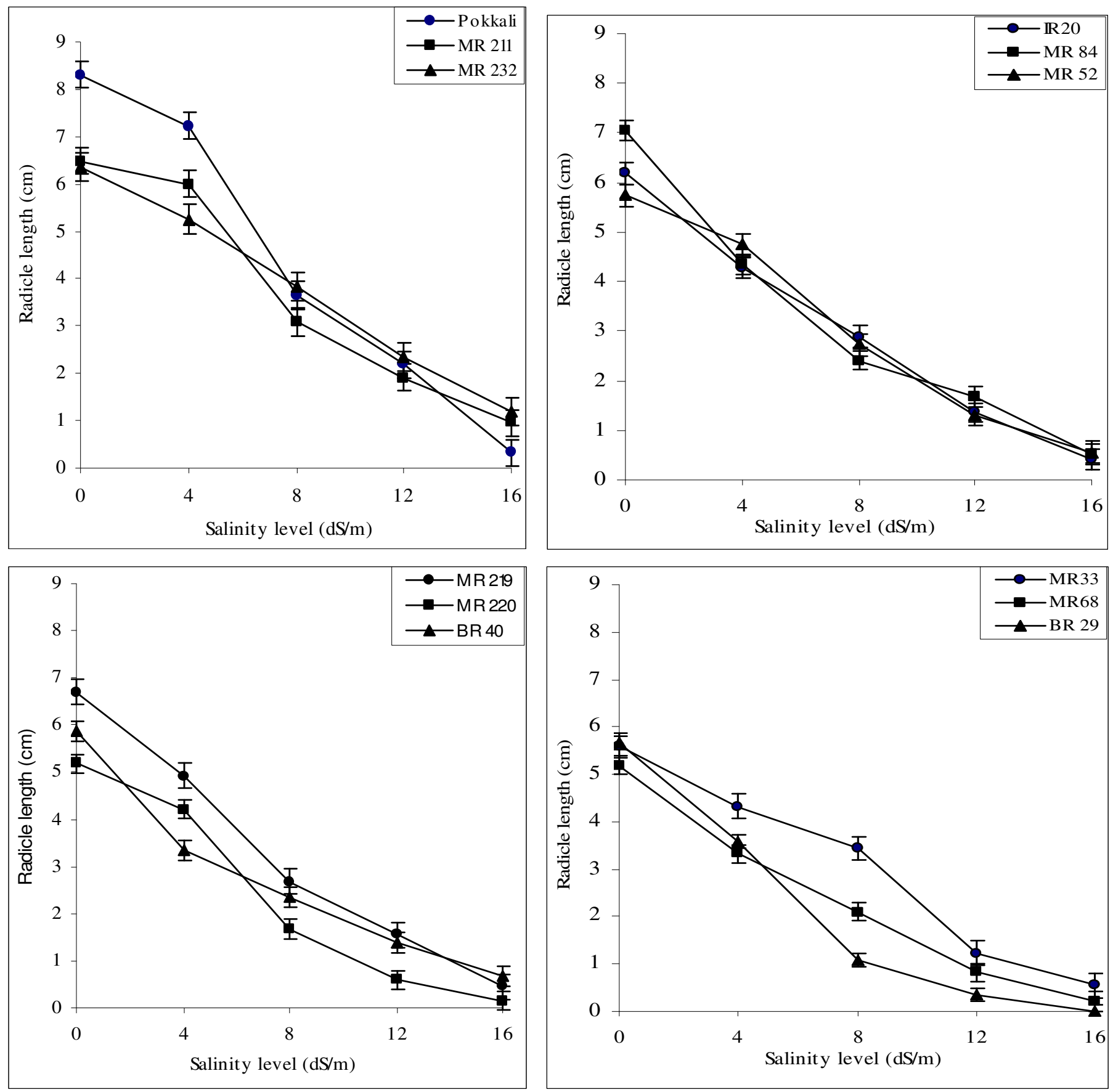

Figure 2. Effect of salinity on radicle length $(\mathrm{cm})$ of different rice varieties.

\section{Classification of varieties}

All varieties showed inconsistency on salt tolerant over increasing salt concentration. At an electrical conductivity of $4 \mathrm{dS} \mathrm{m}^{-1}$, three varieties IR-20, MR33, MR211 were salt tolerant $(T)$; six were moderately tolerant (MT) and rest of the three varieties MR84, MR220 and BR29 were moderately susceptible (MS). However, salinity level increased at 8 and $12 \mathrm{dS} \mathrm{m}^{-1}$ as all varieties showed gradual deviation from their previous salt tolerant ranking T to MT, MT to MS and MS to S, respectively. Therefore, in this study, varieties IR-20 and MR211 showed moderately tolerant (MT) at $8 \mathrm{dS} \mathrm{m}^{-1}$ and moderately sensitive (MS) at $12 \mathrm{dS} \mathrm{m}^{-1}$. While under $16 \mathrm{dS} \mathrm{m}^{-1}$, all varieties were susceptible to salinity. Similarly, Fageria (1985) classified rice cultivar based on their dry matter of plant tops of the 8 cultivars out of 54 . They observed that at salinity level of $5 \mathrm{dS} \mathrm{m}^{-1}$, almost all of 8 cultivars were 
Table 4. Effect of salinity on plumule dry weight ( $\mathrm{g} / 10$ plant) of different rice varieties.

\begin{tabular}{|c|c|c|c|c|c|}
\hline \multirow{2}{*}{ Variety } & \multicolumn{5}{|c|}{ Salinity levels $\left(\mathrm{dS} \mathrm{m}^{-1}\right)$} \\
\hline & 0 & 4 & 8 & 12 & 16 \\
\hline IR 20 & $0.033 \mathrm{c}$ & $0.028 \mathrm{de}(15.2)$ & $0.025 \mathrm{bc}(24.2)$ & 0.013 e $(60.6)$ & $0.007 \mathrm{c}(78.8)$ \\
\hline Pokkali & $0.063 \mathrm{a}$ & $0.054 \mathrm{a}(14.3)$ & $0.031 \mathrm{a}(50.8)$ & 0.025 a (60.3) & 0.015 a (76.2) \\
\hline MR 33 & $0.039 \mathrm{bc}$ & $0.033 \mathrm{bc}(15.4)$ & 0.026 b (33.3) & 0.012 h (46.9) & $0.009 \mathrm{bc}(76.9)$ \\
\hline MR68 & $0.031 \mathrm{c}$ & $0.029 \mathrm{~cd}(12.9)$ & $0.020 \mathrm{~cd}(35.5)$ & 0.012 ef $(61.3)$ & $0.002 \mathrm{~d}(93.6)$ \\
\hline MR 84 & $0.066 \mathrm{a}$ & 0.027 e $(60)$ & 0.019 de (71.2) & 0.015 de $(77.3)$ & $0.003 \mathrm{~d}(95.5)$ \\
\hline MR 52 & $0.039 \mathrm{bc}$ & 0.031 c (20.5) & $0.024 \mathrm{bc}(38.5)$ & 0.017 c (56.4) & $0.010 \mathrm{~b}(74.4)$ \\
\hline MR 211 & $0.048 a b$ & 0.039 b (18.8) & $0.029 a b(39.6)$ & 0.024 a (50) & 0.015 a (68.8) \\
\hline MR 219 & $0.037 \mathrm{bc}$ & $0.033 \mathrm{bc}(13.5)$ & $0.024 \mathrm{bc}(35.1)$ & 0.015 de (59.5) & $0.008 \mathrm{bc}(78.4)$ \\
\hline MR 220 & $0.038 \mathrm{bc}$ & $0.029 \mathrm{~cd}(23.7)$ & 0.016 e $(57.89)$ & $0.008 \mathrm{~g}(78.9)$ & $0.003 \mathrm{~d}(92.1)$ \\
\hline MR 232 & $0.044 \mathrm{~b}$ & $0.033 \mathrm{bc}(25)$ & $0.025 \mathrm{bc}(43.2)$ & 0.020 b (56.8) & 0.012 b (72.7) \\
\hline BR 29 & $0.028 \mathrm{c}$ & $0.020 f(21.4)$ & $0.009 f(67.9)$ & 0.004 h (85.7) & $0.002 \mathrm{~d}(92.9)$ \\
\hline BR 40 & $0.043 \mathrm{~b}$ & 0.032 c (25.6) & $0.025 \mathrm{bc}(41.9)$ & 0.014 de (67.4) & $0.010 \mathrm{~b}(76.7)$ \\
\hline
\end{tabular}

Means with the same letter in the columns do not differ significantly $(P \geq 0.05)$. Values in parenthesis indicate percent reduction of respective controls.

Table 5. Effect of salinity on radicle dry weight ( $\mathrm{g} / 10$ plants) of different rice varieties.

\begin{tabular}{|c|c|c|c|c|c|}
\hline \multirow{2}{*}{ Variety } & \multicolumn{5}{|c|}{ Salinity levels $\left(\mathrm{dS} \mathrm{m}^{-1}\right)$} \\
\hline & 0 & 4 & 8 & 12 & 16 \\
\hline IR 20 & $0.035 b$ & 0.026 b (25.7) & 0.020 a (42.9) & 0.014 a (60) & 0.004 c (88.6) \\
\hline Pokkali & $0.070 \mathrm{a}$ & 0.035 a (52.9) & 0.017 b (75.7) & $0.010 \mathrm{~b}(85.7)$ & 0.006 b (91.4) \\
\hline MR 33 & $0.030 \mathrm{~b}$ & $0.025 \mathrm{bc}(16.7)$ & 0.013 c (56.7) & 0.009 bc (70) & 0.004 c (87.3) \\
\hline MR68 & $0.019 c$ & 0.015 e $(21.1)$ & $0.008 d(57.9)$ & 0.006 c (68.4) & $0.002 \mathrm{~d}(89.5)$ \\
\hline MR 84 & $0.028 \mathrm{~b}$ & $0.021 d(25)$ & 0.014 bc (50) & $0.009 \mathrm{bc}(67.9)$ & $0.002 \mathrm{~d}(90.5)$ \\
\hline MR 52 & $0.036 \mathrm{~b}$ & 0.026 b (27.8) & $0.016 \mathrm{~b}(55.6)$ & $0.011 \mathrm{~b}(75)$ & $0.007 \mathrm{ab}(80.6)$ \\
\hline MR 211 & $0.033 \mathrm{~b}$ & 0.026 b 21.2) & $0.020 \mathrm{~b}(51.5)$ & $0.011 \mathrm{~b}(66.7)$ & $0.008 \mathrm{a}(75.8)$ \\
\hline MR 219 & $0.029 \mathrm{~b}$ & $0.021 \mathrm{~d}(24.1)$ & $0.014 \mathrm{bc}(51.7)$ & $0.009 \mathrm{bc}(68.9)$ & 0.006 b (79.3) \\
\hline MR 220 & $0.063 \mathrm{ab}$ & $0.023 \mathrm{~cd}(63.5)$ & $0.010 \mathrm{~d}(84.1)$ & $0.006 \mathrm{c}(90.5)$ & $0.002 \mathrm{~d}(96.8)$ \\
\hline MR 232 & $0.033 b$ & $0.021 \mathrm{~d}(36.3)$ & 0.015 b (54.5) & $0.011 \mathrm{~b}(72.7)$ & $0.006 \mathrm{~b}(81.8)$ \\
\hline BR 29 & $0.019 c$ & 0.015 e $(21.1)$ & $0.009 \mathrm{~d}(64)$ & $0.000 d(100)$ & 0.00 e (100) \\
\hline BR 40 & $0.032 \mathrm{~b}$ & $0.022 \mathrm{~cd}(31.3)$ & $0.014 \mathrm{bc}(56.3)$ & $0.009 \mathrm{bc}(71.9)$ & $0.006 \mathrm{~b}(81.3)$ \\
\hline
\end{tabular}

Means with the same letter in the columns do not differ significantly $(P \geq 0.05)$. Values in parenthesis indicate percent reduction of respective controls.

tolerant, while at $15 \mathrm{dS} \mathrm{m}^{-1}$ all the varieties were susceptible and at $10 \mathrm{dS} \mathrm{m}^{-1}$ the cultivars showed intermediate tolerance.

\section{Conclusion}

It was concluded that germination and early seedling growth of different rice varieties were inhibited by increasing salt concentration. No seed was germinated at $20 \mathrm{dS} \mathrm{m}^{-1}$. In respect to final germination percentage, speed of germination and germination energy of four varieties namely,
MR 211, MR 232, BR 40 and IR20 was found superior at $12 \mathrm{dS} \mathrm{m}^{-1}$ salt concentration level compared to check variety Pokkal. Based on the performance of early seedling dry weight (both plumule + radicle), reduction per centage of the variety MR211and IR-20 showed salt tolerant at $4 \mathrm{dS} \mathrm{m}^{-1}$ salinity level, moderately salt tolerant at $8 \mathrm{dS} \mathrm{m}^{-1}$ salinity level, moderately susceptible at $12 \mathrm{dS}$ $\mathrm{m}^{-1}$ salinity level and susceptible at $16 \mathrm{dS} \mathrm{m}^{-1}$ salinity level. While the variety MR 232 showed moderately tolerant at $4 \mathrm{~d} \mathrm{Sm}^{-1}$ salinity level, moderately susceptible at 8 and $12 \mathrm{dS} \mathrm{m}^{-1}$ salinity level and susceptible at $16 \mathrm{dS}$ $\mathrm{m}^{-1}$ salinity level. 
Table 6. Influence of salinity on total dry matter production ( $\mathrm{g} / 10$ plants) of rice cultivars and their classification to salinity tolerance.

\begin{tabular}{|c|c|c|c|c|c|c|c|c|c|}
\hline \multirow{2}{*}{ Variety } & \multicolumn{10}{|c|}{ Salinity level $\left(\mathbf{d S ~}^{\mathbf{- 1}}\right.$ ) } \\
\cline { 2 - 9 } & $\mathbf{0}$ & $\mathbf{4}$ & $\mathbf{8}$ & $\mathbf{1 2}$ & $\mathbf{1 6}$ & $\mathbf{4}$ & $\mathbf{8}$ & $\mathbf{1 2}$ & $\mathbf{1 6}$ \\
\hline IR 20 & 0.068 & 0.054 & 0.045 & 0.027 & 0.011 & $\mathrm{~T}$ & MT & MS & S \\
Pokkali & 0.133 & 0.083 & 0.054 & 0.035 & 0.021 & MT & MS & S & S \\
MR 33 & 0.069 & 0.058 & 0.039 & 0.021 & 0.006 & T & MS & S & S \\
MR68 & 0.060 & 0.044 & 0.028 & 0.018 & 0.004 & MT & MS & S & S \\
MR 84 & 0.094 & 0.048 & 0.033 & 0.024 & 0.005 & MS & S & S & S \\
MR 52 & 0.075 & 0.057 & 0.040 & 0.028 & 0.017 & MT & MS & S & S \\
MR 211 & 0.081 & 0.065 & 0.049 & 0.035 & 0.023 & T & MT & MS & S \\
MR 219 & 0.066 & 0.052 & 0.038 & 0.024 & 0.014 & MT & MS & S & S \\
MR 220 & 0.101 & 0.052 & 0.026 & 0.014 & 0.005 & MS & S & S & S \\
MR 232 & 0.077 & 0.054 & 0.040 & 0.031 & 0.018 & MT & MS & MS & S \\
BR 29 & 0.053 & 0.040 & 0.018 & 0.004 & 0.002 & MS & S & S & S \\
BR 40 & 0.075 & 0.054 & 0.039 & 0.023 & 0.016 & MT & MS & S & S \\
\hline
\end{tabular}

$\mathrm{T}=$ Tolerant, $\mathrm{MT}=$ Moderately tolerant, $\mathrm{MS}=$ Moderately susceptible, $\mathrm{S}=$ Susceptible .

\section{REFERENCES}

Akbar M, Ponnamperuma FM (1982). Saline soils of South and Southeast Asia as potential rice land. In rice research strategies for the future. IRRI, pp. 265-281.

Amin M, Hamid A, Islam MT, Karim MA (1996). Root and shoot growth of rice cultivars in response to salinity. Bangladesh Agron. J. 6: 4146.

Asana RD, Kale VR (1965). A study on salt tolerance of four wheat varieties. Ind. J. Plant physiol. 8: 5-22.

Ellis RA, Roberts (1981). The qualification of ageing and survival in orthodox seeds. Seed Sci. Technol. 9: 373-409.

Fageria NK (1985). Salt tolerance of rice cultivars. Plant Soil, 88: 237243

Folkard A, Wopereis MCS (2001). Responses of field-grown irrigated rice cultivars to varying levels of floodwater salinity in a semi-arid environment. Field Crop Res. 70: 127-137.

Heenan DP, Lewin LG, McCaffery DW (1988). Salinity tolerance in rice varieties at different growth stages. Aust. J. Exp. Agric. 28: 343-349.

Jamil M, Rha ES (2007). Response of transgenic rice at germination and early seedling growth under salt stress. Pak. J. Biol. Sci. 10: 4303-4306.

Javed AS, Khan MFA (1975). Effect of sodium chloride and sodium sulphate on IRRI rice. J. Agric. Res. (Punjab). 13: 705-710.

Karim MA, Utsunomiya N, Shigenaga S (1992). Effect of Sodium chloride on germination and growth of hexaploid triticle at early seedling stage. Jpn. J. Crop Sci. 61: 279-284.

Khan MSA, Hamid A, Karim MA (1997). Effect of sodium chloride on germination and seedling characters of different types of rice (Oryza sativa L.). J. Agron. Crop Sci. 179: 163-169

Lutts S, Kinet JM, Bouharmont J (1995). Changes in plant response to $\mathrm{NaCl}$ during development of rice (Oryza sativus L.) varieties differing in salinity resistance. J. Exp. Bot. 46: 1843-1852.

Lutts S, Kinet JM, Bouharmont J (1996). NaCl-induced senescence in leaves of rice (Oryza sativa L.) varieties, differing in salinity resistance. Ann. Bot. 78: 389-398.

Massoud FI (1974). Salinity and alkalinity as soil degradation hazards. FAO/UNDP expert consultation on soil egradation. June 10-14, FAO, Rome, p. 21.
Maas EV, Hoffman GJ (1977). Crop salt tolerance-current assessment. Journal of Irrigation and Drainage Division. American Society of Civil Engineering. 103: 115-134.

Maas EV, Hoffman GJ, Chaba GD, Poss JA, Shannon MC (1986). Salt sensitivity of corn at various growth stages. Irrigation Sci. 4: 45-57.

Metternichi Gl, Zinck JA (2003). Remote sensing of soil salinity: potential and constraints. Remote Sensing Environ. 85: 1-20.

Michael D, Peel B, Waldron L, Kevin B (2004). Screening for salinity tolerance in Alfalfa . Crop Sci. 44: 2049-2053

Mondal TK, Bal AR, Dal S (1988). Effect of salinity on germination and seedling growth of different rice (Oryza sativa L.) varieties, J. Indian Soc. Coastal Agric. Res. 6: 91-97.

Mohammed RM, Campbell WF, Rumbaugh MD (1989). Variation in salt tolerance of alfalfa. Arid Soil Res. 3: 11-20.

Reddy PJ, Vaid Y (1983). Note on the salt tolerance of some rice varieties of Andra Pradesh during germination and early seedling growth. Indian J. Agric. Sci. 52: 278-285.

Ruan S, Xue Q, Thlkowska K (2002). Effect of seed priming on germination and health of rice (Oryza sativa L.) seeds. Seed Sci. Technol. 30: 451-458.

Rahman MS, Miyake H, Taheoka Y (2001). Effect of sodium chloride salinity on seed germination and early seedling growth of rice (Oryza sativa L.). Pak. J. Biol. Sci. 4(3): 351-355.

Yeo AR, Flowers TJ (1983). Varietal differences in toxicity of sodium ions within the shoot of rice varieties differing in salinity resistance. Physiol. Plant. 56: 343-348.

Yeo AR, Yeo ME, Flowers SA, Flowers TJ (1990). Screening of rice (Oryza sativa L.) genotypes for physiological characters contributing to salinity resistance and their relationship to overall performance. Theor. Appl. Genet. 79: 377-384. 